December 2019

\title{
Mission-Driven Recordkeeping: The Need for RIM Staff in U.S. Nonprofit Organizations
}

\author{
Emily Mercer \\ San Jose State University, emilyjeanmercer@gmail.com
}

Follow this and additional works at: https://scholarworks.sjsu.edu/ischoolsrj

Part of the Archival Science Commons, Cataloging and Metadata Commons, Collection Development and Management Commons, Information Literacy Commons, Museum Studies Commons, Scholarly Communication Commons, Scholarly Publishing Commons, and the Social Work Commons

\section{Acknowledgements}

The author wishes to thank Karl Hiner, LauraDenise White, the Quell Foundation, and Joshua Zimmerman.

\section{Recommended Citation}

Mercer, E. (2019). Mission-Driven Recordkeeping: The Need for RIM Staff in U.S. Nonprofit Organizations. School of Information Student Research Journal, 9(2). https://doi.org/10.31979/2575-2499.090208 Retrieved from https://scholarworks.sjsu.edu/ischoolsrj/vol9/iss2/8

This article is brought to you by the open access Journals at SJSU ScholarWorks. It has been accepted for inclusion in School of Information Student Research Journal by an authorized administrator of SJSU ScholarWorks. For more information, please contact scholarworks@sjsu.edu. 


\title{
Mission-Driven Recordkeeping: The Need for RIM Staff in U.S. Nonprofit Organizations
}

\author{
Abstract \\ As a robust and growing industry, often with strong ties to communities served, there is much potential \\ for nonprofit organizations to harness powerful and rich databases of cultural information not found in \\ any other sector. Yet research shows that in most cases, nonprofit organizations operate on limited \\ budgets, tight deadlines, and may see the task of properly managing records as counter-productive to the \\ mission of the organization. This research examines the systems of recordkeeping in nonprofit \\ organizations in the U.S. and argues that record keeping staff must be considered an essential \\ component for a nonprofit organization to survive and thrive.

\section{Keywords} \\ nonprofit organizations, records management, databases, knowledge management, mission-driven work

\section{Acknowledgements} \\ The author wishes to thank Karl Hiner, LauraDenise White, the Quell Foundation, and Joshua Zimmerman.

\section{About Author} \\ Emily Mercer is a Master of Archives and Records Administration candidate at San Jose State University, \\ and resides in Portland, Oregon.
}


The nonprofit sector is a robust and growing industry in the United States. According to McKeever (2018), the number of registered nonprofit organizations (NPOs) in the U.S. grew to 1.5 million, at a rate of 10.4\% from 2005-2015. Interestingly, during the recession of 2007-2009, employment in corporate jobs decreased by $6.2 \%$, whereas employment in the nonprofit sector increased by $4.4 \%$, suggesting that the nonprofit industry is resilient to market fluctuations (Friesenhahn, 2016). In 2015, \$985.4 billion was contributed to the U.S. economy from nonprofits (McKeever, 2018). In 2017, there was a high employment rate in NPOs, with about 12.5 million jobs, making up $10.2 \%$ of private sector employment (Bureau of Labor Statistics, 2019). However, research from the San Jose State University School of Information analyzed job openings for information professionals in 2019 and found that nonprofit organizations had just $1 \%$ representation among employers seeking information professionals (SJSU School of Information, 2019). This essay explores the social and the practical aspects of this problem, and proposes that the work of dedicated Records and Information Management (RIM) staff can be a powerful solution to improving the U.S. nonprofit sector as a whole. Improving the stewardship of these records makes an organization more effective and increases the chance of discovery for future generations. As a note of clarification, many archival, special collection, and historical societies operate as nonprofit organizations. This essay, however, focuses specifically on NPOs whose primary mission revolves around issues not directly related to recordkeeping or archiving, such as those working on civil and human rights, education, the environment, animal protection, or human services.

\section{A Knowledge Management Approach to Records and Information Management}

The International Organization for Standardization (ISO) defines records management (which, for the purposes of this research, is used interchangeably with RIM) as a:

"field of management responsible for the efficient and systematic control of the creation, receipt, maintenance, use and disposition of records, including processes for capturing and maintaining evidence of and information about business activities and transactions in the form of records" (ISO, 2016, p. 3).

Through effective records management, an organization (nonprofit or for-profit) is able to more effectively achieve their mission with intentional planning and follow-through with workflows surrounding information and data. In the nonprofit sector it can be argued that information is an NPO's most powerful strength. Academic research has looked at this topic from a variety of perspectives, such as implementation of general technology in NPOs (Merkel et al., 2007; Saidel \& Cour, 2003) and communication models among and within NPOs (Goecks, Voida, Voida, \& Mynatt, 2008; Vaast, 2004). Much of the research has investigated the domain of knowledge management (KM) in NPOs (Hurley \& Green, 2005; Iverson \& Burkart, 2007; Iverson \& McPhee, 2002; Matzkin, 2008; Renshaw \& Krishnaswamy, 2009). 
$\mathrm{KM}$ is explored here as a related topic to RIM, and is defined by Kinney (1998) as "[t]he process by which an organization creates, acquires and uses knowledge to support and improve the performance of the organization" (p. 2). KM can be understood from two different perspectives: information-based, and people-based (Iverson \& McPhee, 2002). Information-based knowledge management is concerned with the documentation of practical processes that emerge from a given workplace. People-based KM relates to the intangible skills that are developed over time and in social, less quantifiable situations. These forms of knowledge can also be known as explicit and tacit, respectively (Renshaw \& Krishnaswamy, 2009). Both perspectives of the KM field can provide valuable insight into NPO recordkeeping practices, but the informationbased approach is often overlooked in KM literature. Iverson and McPhee speculate that this is because of the belief that this approach reduces complex knowledge to mere data and ignores social context. Though both are concerned with upholding a process which allows NPOs to produce the most value from the shared knowledge of NPO workers and members.

\section{The Social Aspect of NPOs}

Social context is at the core of mission-driven work (Goecks et al., 2008; Hurley \& Green, 2005; Iverson \& McPhee, 2002; Klassen, 1990; Merkel et al., 2007; Vaast, 2004). Goecks et al. (2008) speak specifically about the fundraising domain of NPOs and comment on existing technology capitalizing on the fundamentally collaborative nature of NPOs. Hurley and Green (2005) remark that the only way that KM principles can excel in the nonprofit industry is to discourage "knowledge hoarding" and encourage workplace values around collaboration and knowledge sharing. Iverson and McPhee (2002) discuss KM within communities of practice (COPs), and define a COP as "a set of people who share a concern, a set of problems, or a passion about a topic, who deepen their knowledge and expertise in this area by interacting on an ongoing basis" (p. 260). NPOs are under the umbrella of COPs, and Iverson and McPhee (2002) discuss the ways in which management must cultivate collaboration in order for COPs to reach their full potential. COPs build complex communication networks of various stakeholders centered around strongly held values and share knowledge organically. Merkel et al. (2007) describe the work of NPOs as "fundamentally social," and argue that one must submerge themselves in the network of connections in order to advance professionally in the nonprofit sphere.

Two important terms are introduced by Iverson and Burkart (2007). "Reification" is the process of documenting a previously abstract thought or workflow for subsequent retrieval. "Commodification" is a resulting process of reification whereby information becomes a product which can be copied and shared. As previously discussed, NPOs are very much driven by ideals, and employees of NPOs are fueled by the personal connections they make within their network. Iverson and Burkart (2007) believe that reification and commodification could lead to isolation, however, detracting from the face-to-face interactions that are so crucial to the work of an NPO, and also stifling creativity in the workplace. This concept points to an important possible factor in the reluctance of NPOs to consider RIM as high priority. From research on volunteer coordinators, a 
sentiment emerged that interaction with volunteers was the "real" work of their role, and that the data entry and maintenance required to keep accurate lists and schedules for volunteers was considered a hindrance (Voida, Harmon, \& Al-Ani, 2011). As an alternative, Iverson and Burkart (2007) propose an integration process which continually ties reified information back to organizational missions, uses limited work-flows, and provides ample opportunity for human contact. With this alternative, the business process surrounding the information workflow might be unique for an NPO, as compared with a for-profit business, but the NPO can still derive value from having a systematic and thoughtful approach to the handling of information.

\section{The Practical Information Needs of NPOs}

Approximately $40 \%$ of NPOs rely on volunteers, and research from one study shows that $62 \%$ of volunteer coordinators employed at NPOs have little to no training in information management (McKeever, 2018; Voida et al., 2011). As a result, these volunteer coordinators have created "homebrew" databases, leading to redundancies, duplications, and lost data (Voida et al., 2011). Many of these databases involve computer applications which were not designed for records management, and/or paper files. Approximately 33\% of participants from this study work for an NPO which has implemented an enterprise level database, but none of these participants have fully migrated all of their data. They feel that they are unable to fulfill the role of both human resources coordinator and database administrator, and furthermore, do not enjoy database administration. One participant said they feel guilty delegating this task to a volunteer (Voida et al., 2011).

Most studies on NPO RIM methodology only focus on specific points within the data collection workflow (Benjamin, Voida, \& Bopp, 2018). Benjamin et al. (2018) examine the full lifecycle of data at NPOs, and NPOs as agents within a larger data ecosystem. Similar to other studies, Benjamin et al. (2018) find that the NPOs they studied work in fragmented data systems, resulting in redundancies and inefficiencies. The records created and used by NPO employees on a daily basis may be poorly maintained, leading to inefficiencies in mission objectives, and also affecting the availability of these records for archival uses. Other obstacles NPOs face are problems of scale and an inherent ad hoc nature to the work (Klassen, 1990).

Referring back to Iverson and McPhee (2002), we again see examples of the belief that people-centered relationships and records-based data are mutually exclusive. There is nothing inherently contradictory in these domains, however, and in fact, each could support the other. The complex and multifaceted aspects of evolving relationships captured in the form of a database such as a CRM (customer relationship management system, or constituent relationship management in the case of NPOs) have the potential to allow NPOs to work more efficiently by holding this complex data in streamlined and accessible forms.

\section{The Unique Advantage of Specialized RIM Staff}

Leaders in the RIM field contend that communication and relationships are a fundamental aspect of their work, just as they are for programmatic NPO staff. As 
a contributing author to Leading and Managing Archives and Records Programs, Chosky (2008) considers that the records manager uniquely has the ability to communicate, advocate for, train, and receive buy-in from employees at all levels within an organization, as the records management program touches all aspect of an organization's workflow (Dearstyne, 2008). Chosky comments on the interpersonal skills required to effectively interface with a range of different styles and needs, while also delivering a functional records management system which is in compliance with federal government regulations. The information professional not only can take the pressure off of other staff who predominantly work in a direct service capacity, but can also have the training and aptitude to communicate with other members of these communities of practice on their own terms. A records manager employed at an NPO could be fully responsible for creating a RIM program which integrates reified information to organizational missions, limiting workflows, and making space for interaction, just as Iverson and Burkart (2007) suggest.

Lastly, it is important to address a prevailing notion that NPOs must spend as little as possible on overhead and administrative needs. This kind of thinking could prevent nonprofit leadership from seeing the potential of a designated RIM staff. However, Pallotta (2013) makes a powerful argument that this belief is outdated and keeps the nonprofit sector from growing to transformational levels. He states "it makes us think that overhead is a negative, that it is somehow not part of the cause. But it absolutely is, especially if it's being used for growth" (Pallotta, 2013, n.p.). Pallotta calls for a change in thinking which allows nonprofits to dream big, and invest in staffing and administration, because this will ultimately have a greater impact towards the mission of the organization. RIM staff can ensure that an NPO's information organization, compliance, security and accessibility saves staff valuable time, as well as ultimately saving money for the organization.

\section{An Archival Approach}

The records created and maintained by nonprofit organizations in the United States often have significant value for understanding cultural and historical events. The information contained within these records may have important future cultural, social, and scientific use. Many NPOs are working on improving sociopolitical, environmental, or educational conditions. As such, they are typically very close to the causes and conditions of their mission-driven work. Nonprofit organizations allow a unique perspective on American life: tracking movements of social change and self-organizing individuals who volunteer personal time and resources and are driven by ideology rather than commerce (Klassen, 1990). Approximately $25 \%$ of U.S. adults volunteered 8.8 billion hours, with a value of $\$ 195$ billion, according to McKeever (2018). Most NPOs are operating on limited resources/staff and tight deadlines, which results in missed opportunities for effective preservation of records with archival value. Where preservation efforts are outside of the scope of an NPO's ability and budget, a designated RIM professional would be able to ensure that records are well curated with metadata intact and facilitate transfer to an archival repository, so that future researchers can gain value from the knowledge contained within. 


\section{Conclusion}

Information is a tremendous asset. It improves strategy, strengthens connections with stakeholders, and gives work greater meaning. The culture of the nonprofit sector is centered around relationships formed, and just as face-to-face interpersonal relationships are considered an essential part of nonprofit work, so too should the planning, creation and maintenance of the information these nonprofits keep. This research emphasizes the challenges that NPOs face, while managing informational assets, focusing on the problem from two perspectives of knowledge management: information-based and people-based. RIM professionals have unique qualifications that blend well with the culture of NPOs and could help the organization grow to new levels. This will not only have value to the NPOs themselves, but also to society at large through NPO donations to archival facilities. 


\section{References}

Benjamin, L. M., Voida, A., \& Bopp, C. (2018). Policy fields, data systems, and the performance of nonprofit human service organizations. Human Service Organizations Management, Leadership and Governance, 42(2), 185-204. https://doi.org/10.1080/23303131.2017.1422072

Bureau of Labor Statistics. (2019, April 5). District of Columbia had highest share of employment in nonprofits, Nevada the lowest, in 2017. Retrieved from https://www.bls.gov/opub/ted/2019/district-of-columbia-had-highest-share-ofemployment-in-nonprofits-nevada-the-lowest-in-2017.htm

Dearstyne, B. (2008). Leading and Managing Archives and Records Programs. New York, NY: Neal-Schuman.

Friesenhahn, E. (2016). Nonprofits in America: New research data on employment, wages, and establishments. Monthly Labor Review, 501(2), 1-14. https://doi.org/10.21916/mlr.2016.9

Goecks, J., Voida, A., Voida, S., \& Mynatt, E. D. (2008). Charitable technologies: Opportunities for collaborative computing in nonprofit fundraising. In Proceedings of the 2008 ACM conference on Computer supported cooperative work 2008, 689-698. https://doi.org/10.1145/1460563.1460669

Hurley, T. A., \& Green, C. W. (2005). Knowledge management and the nonprofit industry: A within and between approach. Journal of Knowledge Management Practice, 6(1), 1-10. Retrieved from http://www.tlainc.com/articl79.htm

International Organization for Standardization. (2016). Information and documentation records management - part 1: Concepts and principles. Retrieved from https://www.iso.org/standard/62542.html

Iverson, J., \& Burkart, P. (2007). Managing electronic workflows: Enterprise content management at work in nonprofit organizations. Nonprofit Management \& Leadership, 17(4), 403-419. https://doi.org/10.1002/nml.160

Iverson, J., \& McPhee, R. (2002). Knowledge management in communities of practice. Management Communication Quarterly, 16(2), 259-266. https://doi.org/10.1177/089331802237239

Kinney, T. (1998). Knowledge management, intellectual capital and adult learning. Adult Learning, 10(2), 2-3.

Klassen, D. J. (1990). The archival intersection: Cooperation between collecting repositories and nonprofit organizations. The Midwestern Archivist, 15(1), 24-38. 
Matzkin, D. S. (2008). Knowledge management in the Peruvian non-profit sector. Journal of Knowledge Management, 12(4), 147-159. https://doi.org/10.1108/13673270810884318

McKeever, B.C. (2018, December 13). The Nonprofit sector in brief 2018: Public charities, giving, and volunteering. Retrieved from https://nccs.urban.org/publication/nonprofit-sector-brief-2018

Merkel, C., Farooq, U., Xiao, L., Ganoe, C., Rosson, M. B., \& Carroll, J. M. (2007). Managing technology use and learning in nonprofit community organizations: Methodological challenges and opportunities. CHIMIT '07 Proceedings of the 2007 Symposium on Computer Human Interaction for the Management of Information Technology, 10. https://doi.org/10.1145/1234772.1234783

Pallotta, D. (2013, March). The way we think about charity is dead wrong [Online Video]. Retrieved from https://www.ted.com/talks/dan_pallotta_the_way_we_think_about_charity_is_dead_ wrong

Renshaw, S., \& Krishnaswamy, G. (2009). Critiquing the knowledge management strategies of non-profit organizations in Australia. Proceedings of World Academy of Science, Engineering and Technology, 37, 456-464.

SJSU School of Information. (2019). 2019 MLIS Skills at Work: A Snapshot of Job Postings. Retrieved from https://ischool.sjsu.edu/sites/main/files/fileattachments/career_trends.pdf

Saidel, J. R., \& Cour, S. (2003). Information technology and the voluntary sector workplace. Nonprofit and Voluntary Sector Quarterly, 32(1), 5-24. https://doi.org/10.1177/0899764002250004

Vaast, E. (2004). O brother, where are thou? From communities to networks of practice through intranet use. Management Communication Quarterly, 18(1), 5-44. https://doi.org/10.1177/0893318904265125

Voida, A., Harmon, E., \& Al-Ani, B. (2011, May). Homebrew databases: Complexities of everyday information management in nonprofit organizations. Proceedings of the SIGCHI Conference on Human Factors in Computing Systems, 915-924. https://doi.org/10.1145/1978942.1979078 